\title{
A Glimpse of Sources for Historical Studies at the ETH Archive in Zürich
}

Nicola Oswald and Klaus Volkert (both Bergische Universität Wuppertal, Germany) ${ }^{1}$

\section{An institution and its archive}

The Eidgenössische Technische Hochschule ${ }^{2}$ in Zürich was founded in 1855 as the Eidgenössische Polytechnische Schule, a name often abbreviated to Eidgenössisches Polytechnikum. It was one of the first institutions created and run in Switzerland by the Eidgenossenschaft (Swiss Federation) after the political reorganisation in 1848. This is important in order to understand its function and that of its archives. The polytechnic was headed by the Schweizerische Schulrat (Swiss School Board), a board with four members plus its president, elected by the Bundesrat in Bern. The president of the board was a full-time position with an office at the school; the other members met only a few times a year. There was also a director of the polytechnic but, for a long time, he did not have significant influence in the school.

Nearly all administrative correspondence was in the school itself and this is conserved in its archive. Quite a bit of it is accessible online. Important parts from the administrative archive are the Schulratsprotokolle, including the reports on the meetings of the Schulrat, the Präsidialverfügungen (the orders given by the Schulratspräsident) and the Anhänge, the calendars of the Polytechnic, also called the Polyprogramme. In the archive, there are many more documents concerning the Schulrat, including its Missiven, which are letters and documents sent by the Schulratspräsident, and the Schulratsakten, documents, and in particular letters, received by the Schulrat. At the archive of the ETH, one can find, for example, letters written by R. Dedekind and by B. Riemann (see Figure 1) applying for the vacant position of professor of mathematics at the polytechnic (1858). ${ }^{3}$

So, in respect to administrative information, the situation at the ETH is very convenient for the user - in particular, because many of these documents are now digitised and therefore easily accessible.

\footnotetext{
1 We want to thank Evelyn Boesch, Monica Bussmann and Wiebke Kolbmann from the archives and collections of the ETH and Norbert Hungerbühler as well as Urs Stammbach (Department of Mathematics of the ETH) for their kind assistance. Volker Remmert (Wuppertal) and David Rowe (Mainz) read the manuscript and made valuable suggestions. Peter Morley and Nadine Benstein (both at Wuppertal) helped us with the English language.

2 This name was officially given to the school in 1911.

3 See Volkert 2017 for more details on that nomination.
}

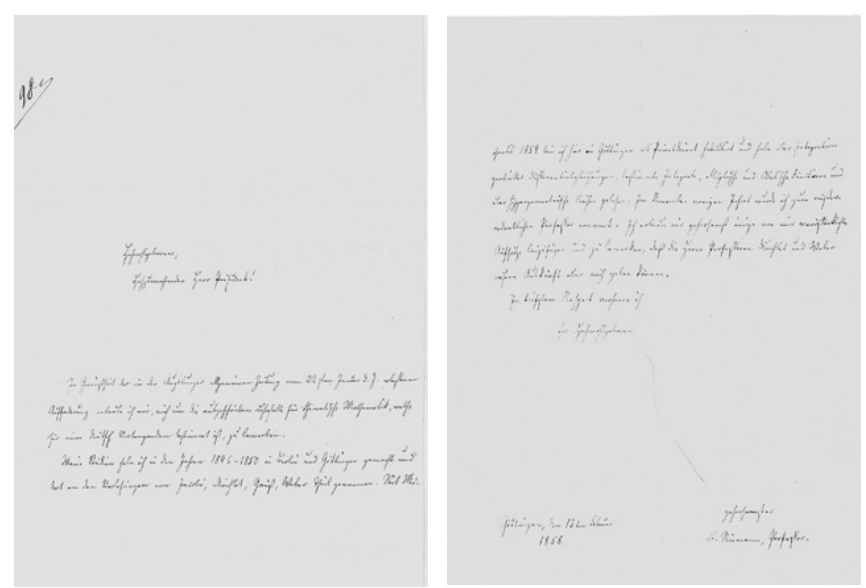

Fig. 1. Riemann applies for the position of professor of pure mathematics at the polytechnic in Zürich (13 June 1858). ${ }^{4}$

Transliteration:

"Hochwohlgeborener

Hochzuverehrender Herr Präsident!

In Anbetracht der in der Augsburger Allgemeinen Zeitung vom 22ten d. J. erlassenen Aufforderung erlaube ich mir, mich auf die ausgeschriebene Lehrstelle für reine Mathematik, welche für einen deutsch Vortragenden bestimmt ist, zu bewerben.

Mein Studium habe ich in den Jahren 1846-50 in Berlin und Göttingen gemacht und dort an den Vorlesungen von Jacobi, Dirichlet, Gauß, Weber theilgenommen. Seit Michaelis 1854 bin ich hier in Göttingen als Privatdocent habilitiert und habe über Integration partieller Differentialgleichungen, bestimmte Integrale und elliptische und Abel'sche Functionen und über hypergeometrische Reihen gelesen. Im November vorigen Jahres wurde ich zum außerordentlichen Professor ernannt. Ich erlaube mir gehorsamst, einige von mir veröffentlichte Aufsätze beizufügen und zu bemerken, daß die Professoren Dirichlet und Weber ihnen Auskunft über mich geben können.

In höflichem Respekt verbleibe ich

Ew. Hochwohlgeboren

Göttingen, den 13. Februar

1858

Gehorsamst

Professor B. Riemann"

\footnotetext{
4 ETH-Bibliothek, Hochschularchiv, Anmeldungen für theoretische Mathematik 1858, Hs 1230: 181. Riemann's application had no success and his friend Dedekind was appointed (see below).
} 
Riemann's letter was addressed to Karl Kappeler (18161888), the president of the school board (1857-1888), and handed to the director of the school (W. von Deschwanden). Kappeler was perhaps the most famous president of the polytechnic; he had the idea to promote pure mathematics at the polytechnic in order to strengthen its scientific standing. As is demonstrated by the list of mathematicians below, he was very successful in doing so. Kappeler visited the professorship candidates in order to get an impression of their teaching and their personalities. ${ }^{5}$ At Göttingen, Kappeler was impressed by Dedekind's teaching whereas Riemann's did not convince the president. Of course, Kappeler also asked the opinion of experts and in the case of Dedekind and Riemann, this was Dirichlet.

For a long time, there was no real self-administration at the polytechnic. The director was not elected but appointed and the professors had only rare meetings. Mathematics was part of the so-called sixth department (VI. Abteilung ${ }^{6}$ ), responsible for the training of prospective teachers and providing teaching to other students (for example, future engineers) in basic disciplines such as mathematics and physics. The training of future teachers was a special feature of the polytechnic in Zürich; in almost all of the other polytechnic schools in German speaking regions, it was introduced only later. It was important for the mathematicians of the school because it offered them the opportunity to teach mathematics at a high level. In other words, the professors of mathematics at the Polytechnikum were not forced to provide highly standardised courses for future engineers. Whereas their studies were heavily regulated, the students of the Fachlehrerabteilung had a relatively free hand in choosing their courses, and the professors in choosing the subjects of their courses.

\section{Mathematics and mathematicians at the ETH}

Almost from the beginning of the Polytechnikum, there were two chairs for mathematics (often called pure mathematics), as well as one chair for descriptive geometry and geometry of position ${ }^{7}$ in German, and another chair for mathematics in French. Later in the 19th century, a chair for descriptive geometry in French was created as well. Thus, there was teaching in both German and French - another consequence of the fact that the

\footnotetext{
5 This procedure is nicely described in a letter (1866) from C. Culmann, a famous professor of construction at Zürich Polytechnic, to K.M. Bauernfeind (see Maurer 1988, 281282).

6 Other names were Fachlehrer or Allgemeine Abteilung. Of course, the structure of the polytechnic underwent changes. The structure described above was introduced in 1865 by the first revision after the polytechnic was founded in 1855 . It lasted, with some slight modifications (e.g. the VI. department was divided into two departments later - one for future teachers and one for the disciplines of general interest), for the rest of the century. Our presentation is mostly focused on the second half of the 19th century.

7 Today, we would say projective geometry. The name Geometrie der Lage was a reference to von Staudt's book (1847).
}

school was run by the Swiss Federation. The list of German speaking mathematicians is highly impressive:

Bruno Elwin Christoffel (1862-1869), Friedrich Prym (1865-1869), Hermann Amandus Schwarz (1869-1875), Georg Frobenius (1875-1892), Friedrich Schottky (18821892), Heinrich Weber (1870-1875), Adolf Hurwitz (1892-1919), Hermann Minkowski (1898-1902), Hermann Weyl (1913-1930) and Heinz Hopf (1931-1965). ${ }^{8}$

There were also other professors (without a chair) like Carl Friedrich Geiser (1873-1913) and Ferdinand Rudio (1889-1929). The German-speaking chair for descriptive geometry was occupied by Wolfgang von Deschwanden (1865-1866) then Wilhelm Fiedler (1867-1907) and then Marcel Grossmann (1907-1927). The French-speaking chairs were occupied by Edouard Armand Méquet (1860-1886) and then Jerôme Franel (1886-1929). Marius Lacombe (1894-1908) was responsible for the teaching of descriptive geometry.

Between 1859 and 1881, there were mathematicians at the so-called Vorschule providing preliminary courses to future students in order to improve their mathematical knowledge. Among them were Johannes Orelli and Gustav Stocker, the latter also serving as secretary to the Schulrat.

Many of the mathematicians listed above came to Zürich quite early in their careers and left Zürich again some years later, therefore leaving few traces in the archive. Others, like Hurwitz and Hopf, spent a long time in Zürich until their retirement and their estates, or parts of them, were passed to the archive. Of particular interest are the inventories named Handschriften and Autographen der ETH-Bibliothek. These are inventories of the estates, or parts of estates, given to the ETH-archive. Such inventories exist for the following mathematicians: ${ }^{9}$ Alexandroff [copies of his correspondence, in particular letters by E. Noether], Bernays, Burckhardt, Bützenberger, Deschwanden, ${ }^{10}$ Wilhelm Fiedler, Ernst Fiedler, Finsler, Grossmann, Herzog, ${ }^{11}$ Hopf, Kollross, Pólya, Jakob Steiner, ${ }^{12}$ van der Waerden ${ }^{13}$ and Weyl.

In Hurwitz' case, the inventory has the title "Die mathematischen Tagebücher und der übrige handschriftliche Nachlass von Adolf Hurwitz (1859-1919): Katalog". This catalogue was prepared by Hurwitz' friend George Pólya (1887-1985). Through it, you get a lot of information of where to find what kind of document as well as information concerning the origin of selected documents.

8 For more information, see Frei/Stammbach 2007. The dates indicate the period when the people served as professors at the polytechnic.

9 Here, only some names are mentioned, and, of course, there are others. Note that these mathematicians were not all professors at the ETH.

${ }^{10}$ Because Deschwanden was the first director of the polytechnic, there is a lot of administrative correspondence by him in the archive.

${ }^{11}$ Herzog also served as director of the polytechnic.

12 This is only a part of his estate - mainly manuscripts for publications and lecture notes taken by his students. The material in Zürich comes from Kollros, who was an active member of the Steiner committee. Bützberger was also a great expert in Steiner studies and, of course, Geiser was his grandnephew.

${ }^{13}$ This is a collection of van der Waerden's correspondence. 
In particular, you can find Hurwitz' Mathematische Tagebücher (Mathematical Diary) in 29 booklets, an important source on his mathematical ideas. ${ }^{14}$

Turning the pages of Hurwitz' diary, amongst the numerous advanced entries on geometry, number theory, analysis, etc., probably the most surprising entries deal with topics from recreational mathematics, e.g. on mathematical origami and puzzles circulating at his time in the mathematical community. This glimpse of the private Hurwitz indicates the broad interest he had in mathematics and not only at the high level of his excellent research. Another peculiar entry in his last diary, bearing the date 20 May 1918, deals with Arthur Cayley's work on counting the isomers of hydrocarbons $\mathrm{C}_{n} \mathrm{H}_{2 n+2}$ (so-called alkanes or paraffins). Extending Cayley's approach, Hurwitz employed generating functions to find an explicit formula for the number of these chemical compounds with exactly three primary carbons, namely

$$
[(\mathrm{n}(\mathrm{n}-2)+4) / 12]
$$

where $[\mathrm{x}]$ denotes the largest integer less than or equal to $\mathrm{x}$. Since carbons have valency four, they may be classified with respect to the number of adjacent carbons, so Hurwitz was counting those isomers having exactly three carbons each of which bound to only one further carbon (see Figure 2).${ }^{15}$ In view of the later work by George Pólya [Pólya 1937], another prominent mathematician of the ETH and curator of Hurwitz' estate, it might be surprising that such an explicit formula is possible. Pólya succeeded in providing asymptotic formulae for chemical compounds (such as, for example, isomers of alkanes, alcohols, etc.) of exponential growth (with respect to the number of carbons). However, his enumeration method applies to the set of all isomers of hydrocarbons and the very special isomers Hurwitz was studying and counting constitutes only a tiny subclass. We may speculate whether Pólya was inspired for his research by this entry in Hurwitz' diary. ${ }^{16}$

Furthermore, there is a huge number of Hurwitz' meticulously handwritten manuscripts of lectures throughout his academic life.

Many of the aforementioned inventories have been digitised and there are more to follow. The Findbuch of the Hopf estate, for instance, contains 14 pages with dense information on Hopf in three parts: I. manuscripts, II. correspondence, III. documents concerning Hopf's biography. Of course, not all estates are as rich as Hopf's. His correspondence is very interesting, not least because he lived in neutral Switzerland and thus could serve as an intermediary between mathematicians in countries at war with each other (see Figure 3 for an example).

${ }^{14}$ Cf. Oswald 2015, Schmidt 2017. For another interesting aspect of Hurwitz' work cf. Helmstetter/Oswald 2016. The Hurwitz' correspondence is preserved today at Göttingen in the Universitätsund Staatsbibiothek. The diary is digitalized by e-manuscripta.ch - the digital platform for manuscript material from Swiss libraries and archives: http://dx.doi.org/10.7891/e-manuscripta-12833.

15 For more information cf. Helmstetter, Oswald 2016.

16 Pólya's enumeration method was anticipated by John Redfield in 1927, however, it was not noticed by the community for a long time.
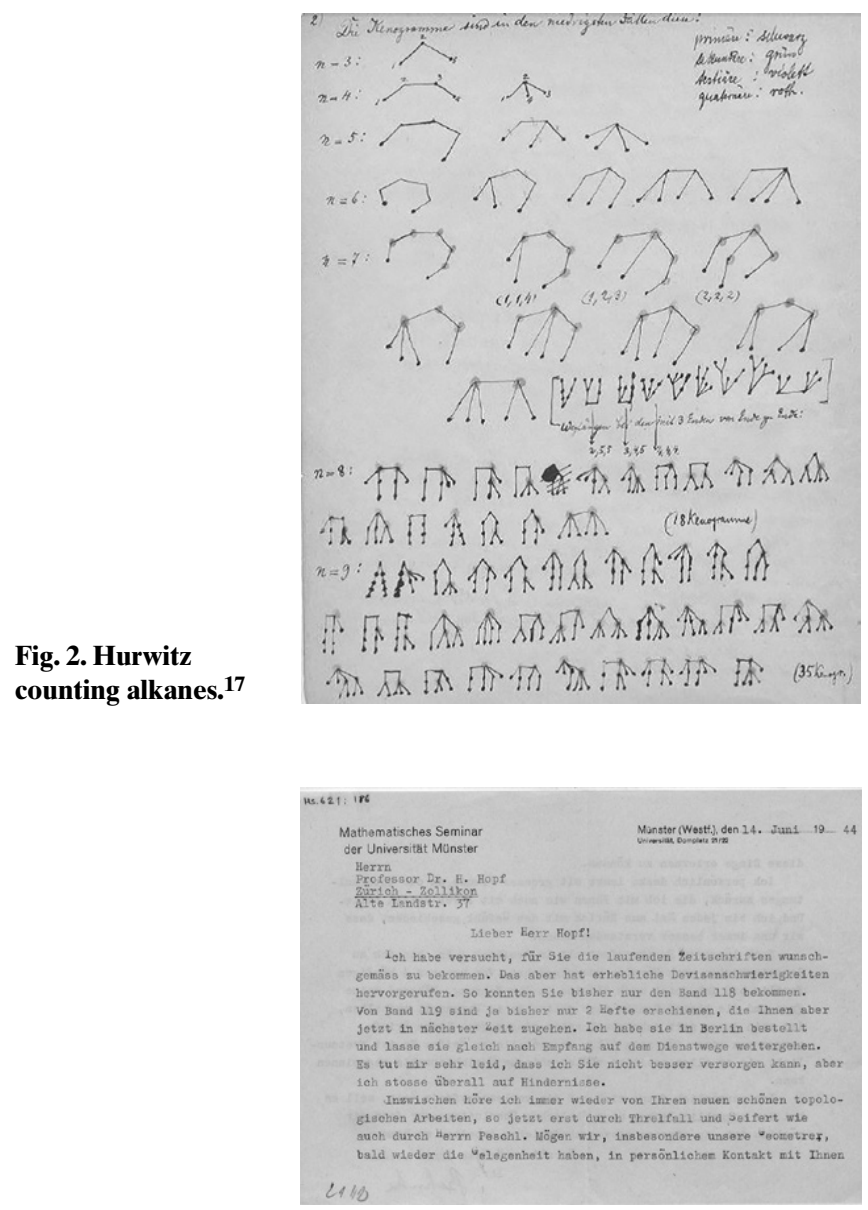

Fig. 3. Communication in wartime (Behnke to Hopf, Münster, 14 June 1944). ${ }^{18}$

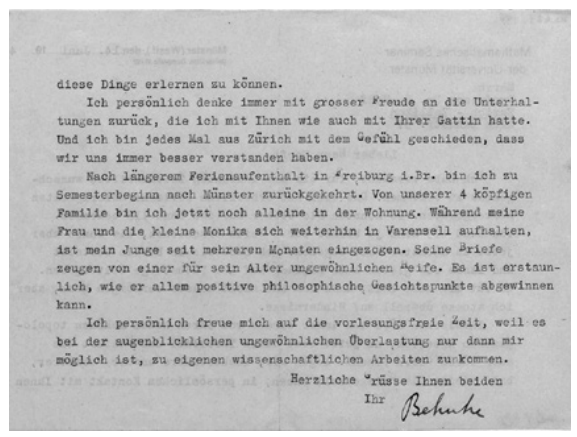

Behnke describes the situation of his family and the difficulties of sending the last issues of the journal Mathematische Annalen to Hopf. He remembers warmly the mathematical discussions he had with Hopf in Zürich during his last visit there.

Soon after the war, Hopf was involved in the rebuilding of mathematics in Germany. ${ }^{19}$ Hopf was a moral and scientific authority with important influence. To some of his German colleagues, it seemed important to justify themselves before that authority. In the ETH-archive, there is a surprising document in which L. Bieberbach (1886-1982) did so (see Figure 4). During the Nazi regime, Bieberbach was the most prominent proponent of the socalled Deutsche Mathematik. Together with Th. Vahlen,

\footnotetext{
17 A. Hurwitz, Mathematisches Tagebuch 30, ETH-Bibliothek, Hochschularchiv, Hs 582:30, page 2 (20. Mai 1918).

${ }^{18}$ ETH-Bibliothek, Hochschularchiv, Hs 621: 186.

${ }^{19}$ See Volkert 2018 for an example.
} 


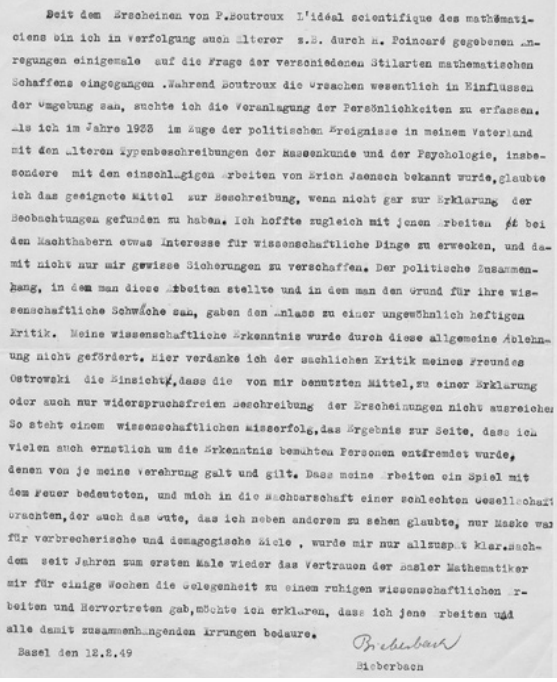

Fig. 4. Letter from Bieberbach to Hopf. 22

he edited the journal with this title. Bieberbach tried to get influence in several contexts like the Deutsche Mathematiker-Vereinigung and the Mathematische Annalen. In Berlin, he created an influential centre of mathematics and he held important positions at the university like dean. ${ }^{20}$ After the war, Bieberbach lost his position; only in 1949 was he invited to Basel by A. Ostrowski to lecture there as a guest. At that point, Bieberbach could hope for some rehabilitation. In his letter to Hopf, ${ }^{21}$ he speaks about his racist theory of types of mathematical thinking. He explains that Poincaré and Klein had similar ideas before him and that he regrets everything.

In case there is no inventory, other documents can be of help: often you can find a Biographisches Dossier on a mathematician created by the archive; Personalakten (personal files) of the professors are conserved at Bern by the Bundesarchiv (archive of the Swiss Federation); and there is a Professorenbuch at the ETH-archive with some information on the professors and their careers. It may be interesting to have a look at the Missiven - because the Schulrat sent appraisals of candidates proposed for the nomination of professor to the Bundesrat, and to the Schulratsakten because sometimes other mathematicians were asked for their opinions on a candidate. The nominations were proposed by the Schulrat but made by the Bundesrat and the nomination procedure was very different to that of the universities. Habilitation was also decided by the Schulrat when demanded by the candidate. The right to assign a doctorate was only given to the polytechnic in 1908. Before that, the candidates had to go to a university - usually in Zürich - to get their degree. The documents on these procedures are conserved in the Staatsarchiv ${ }^{23}$ in Zürich, as are many other administra-

\footnotetext{
${ }^{20}$ See Mehrtens 1987 and Schappacher 1998.

${ }^{21}$ Hopf was of Jewish origin. After a visit to Germany in 1938, he was arrested and had some trouble with the Nazi regime (see Stammbach 2009).

${ }^{22}$ ETH-Bibliothek, Hochschularchiv, 641: 253a.

${ }^{23}$ This is the archive of the Kanton Zürich and it is located in Zürich on the new university campus called Milchbuck. The archive of the Swiss Federation is called Bundesarchiv and is located in Bern.
}

tive documents of the university. From the very beginning of the polytechnic, it was possible to get a habilitation there and so become Privatdozent. The candidate demanded their habilitation at the Schulrat and, when the candidate was viewed positively, they were promoted to Privatdozent. Some names here are Theodor Reye, Heinrich Durège, Carl Friedrich Geiser, Ludwig Stickelberger and Ernst Fiedler.

One can find a lot of lecture notes in the ETH archive. Very nice and legible examples are Marcel Grossmann's lecture notes of courses delivered by Hurwitz, Geiser, Wilhelm Fiedler and others. It was a lucky thing that Marcel Grossmann was very engaged with mathematics and a diligent student - he was able to help his friend Albert Einstein with mathematics. There are also very nice booklets written by one of Grossmann's pupils at the Kantonsschule. It seems characteristic of the situation at the polytechnic that there were strong links to schools like the Kantonsschule: the training of future teachers led to the creation of a network connecting the polytechnic with its surroundings. This is especially significant in the case of Wilhelm Fiedler, who taught future teachers for 40 years in the field of geometry. His son Ernst Fiedler became director of the Industrieschule (later named Oberrealschule) at Zürich and has left some very nice lecture notes on courses given by his father and other professors like Weierstrass. The only difficulty with them is that they were written in shorthand. ${ }^{24}$ Of course, there are further, more specific sources and documents in the archive. You may search for them with the help of the Wissensportal (Knowledge Portal).

Naturally, other interesting people near to mathematics were in Zürich like Einstein, Pauli and Schrödinger. Many documents on them are in the ETH-archive.

From the point of view of the history of mathematics, it may also be interesting to know that there is a small

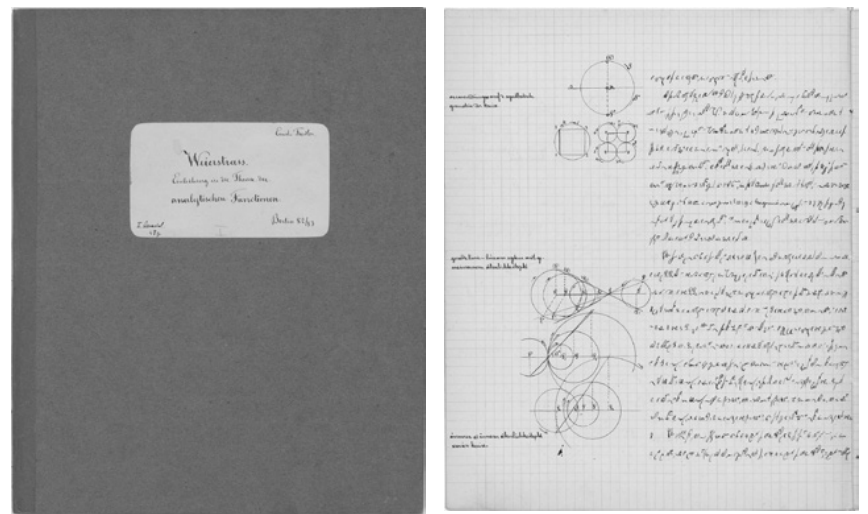

Fig. 5. Pages of Ernst Fiedler's notebooks. ${ }^{25}$

${ }^{24}$ Hermann Weyl also liked shorthand, as did his friend Fritz Medicus, professor of philosophy at the polytechnic (see Eggert 1957).

${ }^{25}$ ETH-Bibliothek, Hochschularchiv, Hs 109 and 110. Title page of a course on analytic functions delivered by Weierstrass at Berlin and a page from lecture notes taken by Ernst Fiedler of a course on Zyklographie delivered by his father Wilhelm Fiedler. 
collection of mathematical models bought by Wilhelm Fiedler in order to support the teaching of descriptive geometry and geometry in general (see Figures 6 and 7). ${ }^{26} \mathrm{~A}$ project on these models is in progress.

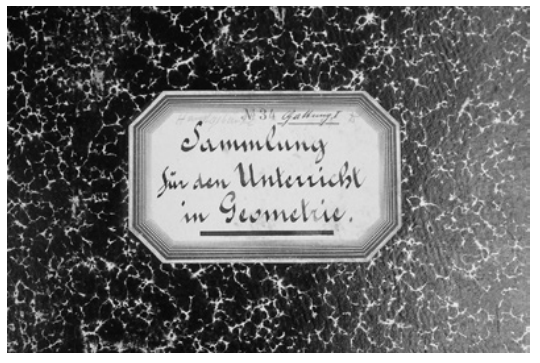

Fig. 6. Front page of the inventory of the collection of models for the teaching of descriptive geometry. $^{27}$

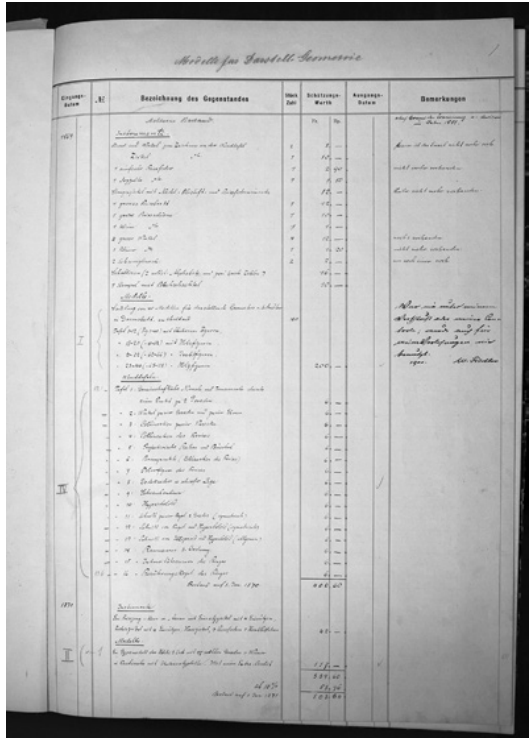

Fig. 7. A page of

Fiedler's inventory: buying models for teaching descriptive geometry in 1869.28

The library of the ETH owns many interesting books and thesises. An inventory with useful comments was published by P. Richter some years ago. ${ }^{29}$

Sometimes you can find surprising and unexpected documents. We end our survey with such a document: a letter by Jacques Feldbau (1914-1945) written in 1942 to Werner Gysin (see Figure 8). ${ }^{30}$ Feldbau was a young Jewish mathematician from Strasbourg (Alsace) who worked on his thesis first at Strasbourg and then - after the transfer of the Strasbourg University to ClermontFerrand in 1940 - at Clermont-Ferrand under the supervision of Charles Ehresmann. The year after he wrote the letter below, he was arrested at Clermont-Ferrand and transported to Auschwitz. He died some days before the end of the war on a Todesmarsch in Bavaria. ${ }^{31}$

\footnotetext{
${ }^{26}$ Besides well-known models sold by Brill and later by Schilling, there are also nice examples produced by Jakob Schröder's firm and self-made objects in this collection.

${ }^{27}$ ETH-Bibliothek, Hochschularchiv, Hs 1196: 30.

${ }^{28}$ ETH-Bibliothek, Hochschularchiv, Hs 1196: 50.

${ }^{29}$ See Richter 2015.

${ }^{30}$ ETH-Bibliothek, Hochschularchiv, Hs 646: 1. Gysin was a graduate student of H. Hopf (like B. Eckmann) working in topology.

${ }^{31}$ See Audin 2012.
}

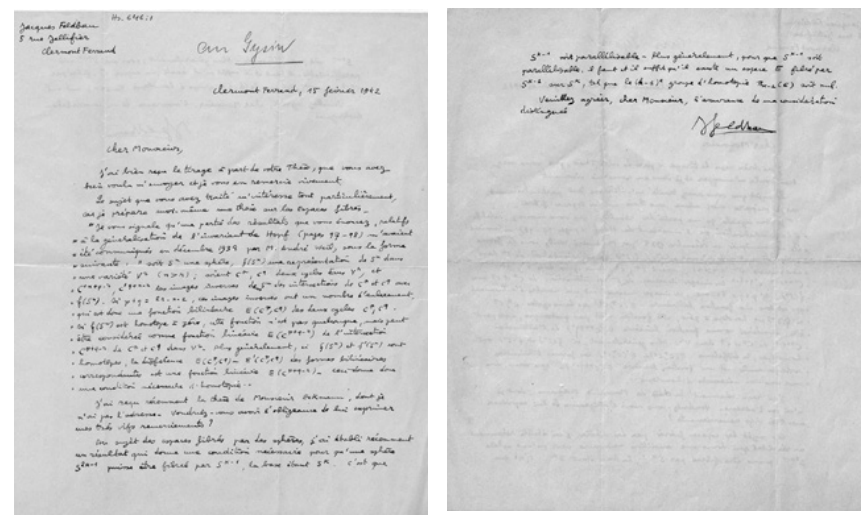

Fig. 8. Letter from Jacques Feldbau to Werner Gysin. ${ }^{32}$

Feldbau thanks Gysin for sending him his thesis. He discusses some results of that thesis and explains that they were communicated to him by André Weil in 1939. Feldbau also thanks B. Eckmann for sending him his thesis and announces some results on fiber spaces that he had discovered recently.

The archive of the ETH is a rich source for interesting documents on the history of mathematics since the middle of the 19th century. Many mathematicians, among them some of the most important ones, worked here, leaving a lot of documents in the archive. It is certainly worth of a visit, not least because you are warmly welcomed here and you get kind and competent assistance from the persons working in the archive. And if you are tired of mathematics, you can go upstairs and have a look at the Max Frisch archive, a famous student of the ETH.

\section{Sources}

Audin, M.: Jacques Feldbau Topologe. Das Schicksal eines jüdischen Mathematikers (1914-1945) [Berlin - Heidelberg: Springer-Spektrum, 2012]. The original was in French: Une histoire de Jacques Feldbau (Paris: Société Mathématique de France, 2010).

Eggert, H.: Ein Dreigestirn stenographierender Professor: Hermann Weyl, Fritz Medicus, Ernst Fiedler (Schweizer Stenograph Heft 10 (1957), 434-438).

Frei, G., Stammbach, U.: Mathematicians and mathematics in Zürich, at the university and the ETH (Zürich: ETH-Bibliothek, 2007).

Helmstetter H., Oswald, N.: Hurwitz's Counting Isomers of Alkanes (Elemente der Mathematik 71 (2016), 57-68).

Maurer, B.: Karl Culmann und die graphische Statik (Berlin u.a.: Verlag für Geschichte der Naturwissenschaften und Technik, 1998).

Mehrtens, H.: Ludwig Bieberbach and Deutsche Mathematik. In: E.R. Phillips (ed.), Studies in the history of mathematics (Washington D.C., 1987), 195-241.

Oswald, N.: Hurwitz faltet Papier (Mathematische Semesterberichte 62 (2015), 123-130).

Pólya, G.: Kombinatorische Anzahlbestimmungen für Gruppen, Graphen und chemische Verbindungen (Acta Mathematica 68 (1937), 145-254).

Richter, P.: Die Entwicklung der Mathematik von der Antike bis 1925. Dokumentiert anhand von Originalausgaben aus den Beständen der Bibliothek der ETH Zürich. 6 Volumes (Klausenburg/Cluj-Napoca: Argonaut, 2015).

$\overline{32}$ ETH-Bibliothek, Hochschularchiv, Hs 641: 1. 
Schappacher, N.: The Nazi era: the Berlin way of politicising mathematics. In: Mathematics in Berlin (Berlin, 1998), 127-136.

Schmidt, Maximilian-Peter: Hurwitz neu entdeckt (MA-Thesis, Department of Mathematics, ETH Zürich, 2017).

Stammbach, U.: Ein Zwischenfall, dem Heinz Hopf 1939 in Karlsruhe ausgesetzt war (Mathematische Semesterberichte 56 (2009), 233250).

Volkert, K.: Dedekind goes Zürich (Mathematische Semesterberichte 64 (2017), 147-158).

Volkert, K.: Vorher - nachher: zwei Briefe des Mathematikers William Threlfall (1933 und 1945) (Mathematische Semesterberichte 65 (2018), 1-14).
Nicola Oswald graduated from the university at Würzburg in number theory. She is now working in the history of modern mathematics, in particular on Adolf Hurwitz, at Wuppertal.

Klaus Volkert is also working at Wuppertal. His main interest being the history of geometry and topology since 1800 , in particular that of descriptive geometry. Both are members of the "AG Didaktik und Geschichte der Mathematik" and the "Interdisziplinäres Zentrum für Wissenschafts- und Technikforschung (IZWT)" of the Bergische Universität Wuppertal. 